\title{
PROFIL LULUSAN PERGURUAN TINGGI SWASTA INDONESIA DITINJAU DARI TEMPAT KERJA LULUSAN
}

\author{
Andri Eko Prabowo ${ }^{1 *}$, Wahjoedi ${ }^{2}$,Sugeng Hadi Utomo ${ }^{2}$, Agung Haryono ${ }^{2}$ \\ e-mail: andri.eko.1704319@ students.um.ac.id
}

${ }^{1}$ Mahasiswa Doktoral Pendidikan Ekonomi, Universitas Negeri Malang, Malang, Indonesia
${ }^{2}$ Dosen S3 Pendidikan Ekonomi, Universitas Negeri Malang, Malang, Indonesia

\begin{abstract}
This study aims to map the workplaces of private university graduates in Indonesia. The research was conducted for 3 consecutive years on graduates from undergraduate programs in private universities in Indonesia. The research was conducted online in May 2017-2019 using a questionnaire from the ministry of research and higher education technology. The data were obtained descriptively and quantitatively in order to obtain results that could describe the actual conditions. The results showed that private university graduates successively chose to work in private companies and government agencies, followed by community and social institutions. Meanwhile, entrepreneurship is the last choice for graduates of private universities in Indonesia.
\end{abstract}

Keywords: workplace, private universities, entrepreneurship, government agencies, community social institutions, private companies 


\section{PENDAHULUAN}

Revolusi industri yang segala bidang telah memberikan dampak besar bagi dunia kerja. Perubahan-perubahan tersebut menuntut antisipasi dan evaluasi perguruan tinggi atas kompetensi yang dibutuhkan dunia kerja. Evaluasi secara berkelanjutan juga perlu dilakukan untuk memperoleh umpan balik dari pengguna dan lulusan, serta untuk mengurangi kesenjangan dunia pendidikan dengan dunia usaha. Dinamika kesenjangan kompetensi dunia usaha dengan pendidikan tinggi telah lama mendapat perhatian dunia dan dikaji oleh beberapa peneliti, seperti penelitian tentang kondisi kerja dan pekerjaannya (Enders \& Teichler, 1997) pendidikan tinggi dan dunia kerja (Teichler, 1999), overview pendidikan tinggi dan dunia kerja(Kogan \& Brennan, 1993), dampak kebijakan pendidikan (Higher Education and the World of Work, 2015)

Permasalahan utama dunia usaha dengan pendidikan terjadi pada meningkatnya jumlah pengangguran terdidik baik pengangguran terbuka dan terselubung sebagai dampak dari meningkatnya jumlah lulusan perguruan tinggi, perubahan kondisi sosial ekonomi dan politik yang mempengaruhi pasar dunia kerja (Supriati \& Handayani, 2018). Selan itu perkembangan pesat ilmu pengetahuan, teknologi informasi dan komunikasi juga mendorong perubahan mendasar dalam kompetensi, kualifikasi, dan persyaratan-persyaratan dalam memperoleh pekerjaan. Permasalahan ketenagakerjaan ini menyangkut banyak aspek kehidupan, sehingga memerlukan suatu kebijakan nasional yang strategis guna mengatasi masalah ketenagakerjaan.

Data yang dikeluarkan oleh Badan Pusat Statistik (BPS) menunjukkan bahwa jumlah pengangguran terbuka lulusan sarjana dari Agustus 2018 sampai Februari 2019 mengalami peningkatan sebesar 90000 orang (Badan Pusat Statistik, n.d.), yang berarti terjadi peningkatan lebih dari 10000 orang setiap bulannya. Kondisi ini perlu mendapat perhatian serius, mengingat saat ini banyak perusahaan melakukan rasionalisasi jumlah tenaga kerja sebagai efek dari kelesuan ekonomi akibat pandemi virus corona.

Pendidikan tinggi berorientasi kompetensi yang dijalankan pemerintah saat ini menitik beratkan pada kemampuan lulusan dalam memenuhi kebutuhan dunia kerja (Disas, 2018). Kebijakan ini diimplementasikan perguruan tinggi melalui penerapan kurikulum berbasis kerja. Hasil dari penerapan kurikulum ini, kemudian dievaluasi melalui daya serap lulusan di dunia kerja (Alam, 2016). Sehingga untuk mengetahui keberhasilan pendidikan dan kualitas lulusan pendidikan tinggi salah satu cara yang dapat dilakukan dengan melihat daya serap lulusan di dunia kerja.

Penelitian ini dilakukan untuk memberikan gambaran kualitas lulusan pendidikan tinggi, yang difokuskan pada tempat lulusan bekerja dalam rentang waktu 2 tahun setelah lulus kuliah. Pemilihan waktu 2 tahun setelah kelulusan didasarkan pada pertimbangan bahwa satu tahun pertama setelah kelulusan merupakan masa transisi pasca study dan lulusan belum memiliki pekerjaan yang tetap. Pada 2 tahun setelah lulus pada umumnya lulusan sudah memiliki pekerjaan yang tetap dan mantap.

\section{METODE PENELITIAN}

Jenis penelitian ini merupakan penelitian survei. Penelitian dilakukan secara daring dengan menggunakan angket resmi dari pemerintah, yaitu kuesioner yang dikeluarkan oleh DIRJEN BELMAWA KEMENRISTEKDIKTI.

Pengambilan sampel dilakukan dengan secara acak pada seluruh lulusan Universitas Islam Riau pada rentang waktu kelulusan tahun 2015-2017. Penelitian dilakukan selama tiga bulan pada setiap bulan Mei hingga Juli pada tahun 20172019. Data hasil penelitian kemudian dianalisis secara deskriptif kuantitatif. 
HASIL DAN PEMBAHASAN

Profil Responden

Responden pada penelitian ini merupakan lulusan perguruan tinggi swasta pada tahun 2015-2017. Pemilihan responden didasarkan pada surat edaran DIRJEN BELMAWA KEMENRISTEK DIKTI No. 471/B/SE/VII/2017 tentang Pelaksanaan Tracer Study. Sebaran responden penelitian ini dapat dilihat pada tabel berikut:

Tabel 1. Responden Penelitian

\begin{tabular}{|l|c|c|c|c|}
\hline $\begin{array}{c}\text { Tahun } \\
\text { lulus }\end{array}$ & $\begin{array}{c}\text { Tahun } \\
\text { Penelit } \\
\text { ian }\end{array}$ & $\begin{array}{c}\text { Jumlah } \\
\text { respond } \\
\text { en }\end{array}$ & Bekerja & $\begin{array}{c}\text { persent } \\
\text { ase }\end{array}$ \\
\hline 2015 & 2017 & 819 & 460 & $56,17 \%$ \\
\hline 2016 & 2018 & 1151 & 606 & $52,65 \%$ \\
\hline 2017 & 2019 & 1033 & 981 & $94,97 \%$ \\
\hline \multicolumn{2}{|l}{ Total Responden } & 3003 & 2047 & $68,17 \%$ \\
\hline
\end{tabular}

Total responden yang terlibat dalam penelitian ini sebanyak 3003 orang, dengan jumlah semakin lama semakin mengecil. Hal ini disebabkan oleh sudah mulai putusnya hubungan komunikasi antar lulusan perguruan tinggi swasta. Data hasil penelitian menunjukkan bahwa terdapat 2047 orang atau $68,17 \%$ yang sudah memiliki pekerjaan tetap, baik bekerja sebagai pegawai pemerintahan, perusahaan swasta, maupun bekerja dengan cara membangun perusahaannya sendiri (berwirausaha)

\section{Profil Kerja Lulusan}

Perguruan tinggi swasta pada umumnya melakukan branding melalui jumlah lulusannya yang bekerja . kondisi ini mendorong perguruan tinggi swasta untuk menyusun kurikulum yang disesuaikan dengan kebutuhan dunia kerja pada saat itu. Hasil penelitian menunjukkan bahwa lulusan program sarjana perguruan tinggi swasta, lebih dari $65 \%$ memilih untuk bekerja pada berbagai lembaga baik negeri maupun swasta, dan terdapat sekitar $20 \%$ lulusan yang memilih untuk berwirausaha. Secara lebih mendetail dapat dilihat pada tabel berikut.
Tabel 2. Status Kerja Lulusan

\begin{tabular}{|c|c|c|c|c|c|c|c|c|}
\hline \multirow{2}{*}{ Status } & \multicolumn{7}{|c|}{ Tahun Lulus } & \multicolumn{2}{c|}{ Jumlah } \\
\cline { 2 - 9 } & $\mathbf{2 0 1 5}$ & $\boldsymbol{\%}$ & $\mathbf{2 0 1 6}$ & $\boldsymbol{\%}$ & $\mathbf{2 0 1 7}$ & $\%$ & $\sum$ & $\%$ \\
\hline Bekerja & 362 & $\begin{array}{c}78,7 \\
\%\end{array}$ & 475 & $\begin{array}{c}78,4 \\
\%\end{array}$ & 568 & $\begin{array}{c}57,9 \\
\%\end{array}$ & 1405 & $\begin{array}{c}68,6 \\
\%\end{array}$ \\
\hline Wirausaha & 91 & $\begin{array}{c}19,8 \\
\%\end{array}$ & 42 & $\begin{array}{c}6,9 \\
\%\end{array}$ & 323 & $\begin{array}{c}32,9 \\
\%\end{array}$ & 456 & $\begin{array}{c}22,3 \\
\%\end{array}$ \\
\hline Lainnya & 7 & $\begin{array}{c}1,5 \\
\%\end{array}$ & 89 & $\begin{array}{c}14,7 \\
\%\end{array}$ & 90 & $\begin{array}{c}9,2 \\
\%\end{array}$ & 186 & $\begin{array}{c}9,1 \\
\%\end{array}$ \\
\hline Total & 460 & & 606 & & 981 & & 2049 & \\
\hline
\end{tabular}

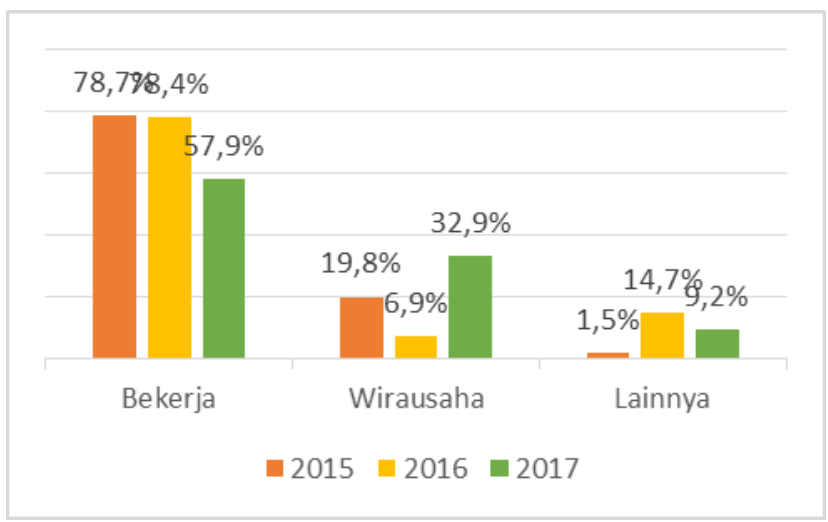

Grafik 1. Status Kerja Lulusan

Tabel dan grafik status kerja lulusan menunjukkan bahwa lulusan yang memilih untuk bekerja pada berbagai lembaga pemerintah, swasta dan LSM memiliki tren yang menurun. Kemudian hasil analisis juga menunjukkan bahwa pilihan menjadi wirausaha menunjukkan tren yang meningkat. Kondisi ini selaras dengan hasil penelitian Asia Pacific Entrepreneurship Survey pada bulan april 2019 yang menyebutkan bahwa 96\% warga indonesia berkeinginan kuat untuk menjadi wirausaha (Herbalife Survey, 2019)

\section{Profil Tempat Kerja Lulusan}

Banyaknya lulusan perguruan tinggi swasta yang memilih bekerja setelah menyelesaikan pendidikannya, memerlukan analisis lanjutan terkait tempat bekerja lulusan tersebut. Hasil analisis data menunjukkan bahwa tempat kerja lulusan di dominasi oleh perusahaan swasta, kemudian diikuti oleh lembaga pemerintahan. Lembaga Sosial Masyarakat kurang mendapat perhatian dari lulusan PTS. 


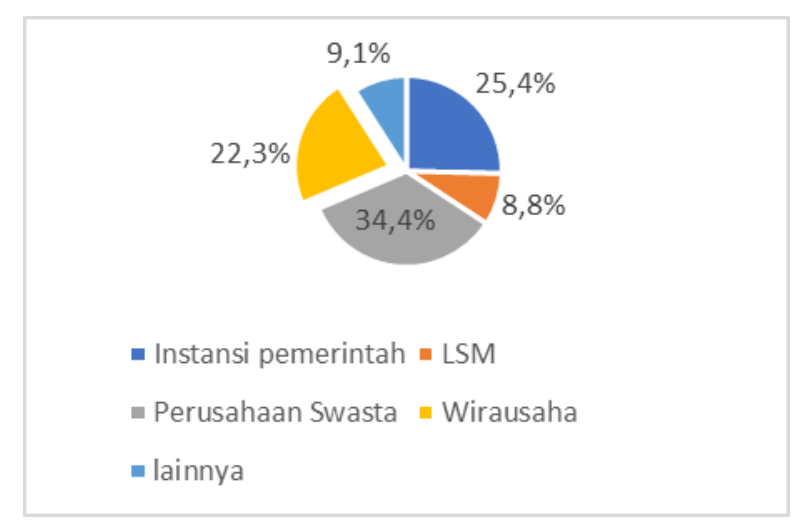

Grafik 2. Tempat Kerja Lulusan

Tabel 3. Sebaran Pekerjaan Responden

\begin{tabular}{|c|c|c|c|c|c|}
\hline \multirow{2}{*}{ Pekerjaan } & \multicolumn{3}{|c|}{ Tahun Lulus } & \multicolumn{2}{c|}{ Jumlah } \\
\cline { 2 - 6 } & 2015 & 2016 & 2017 & $\sum$ & $\%$ \\
\hline Pemerintah & 222 & 223 & 75 & 520 & $25,4 \%$ \\
\hline LSM & 11 & 162 & 8 & 181 & $8,8 \%$ \\
\hline Swasta & 129 & 90 & 485 & 704 & $34,4 \%$ \\
\hline Wirausaha & 91 & 42 & 323 & 456 & $22,3 \%$ \\
\hline Lainnya & 7 & 89 & 90 & 186 & $9,1 \%$ \\
\hline & 460 & 606 & 981 & 2047 & \\
\hline
\end{tabular}

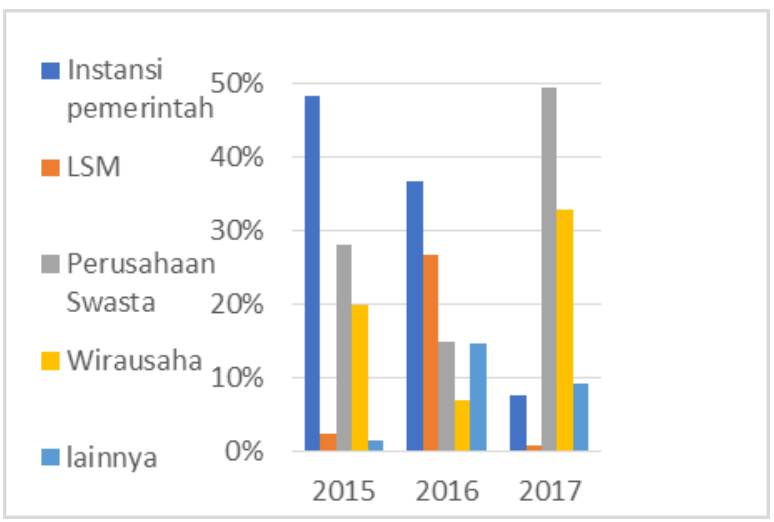

Grafik 3. Sebaran tempat kerja lulusan berdasarkan tahun

Hasil analisis data tempat kerja lulusan menunjukkan bahwa bekerja pada perusahaan swasta dan lembaga pemerintahan mendominasi pilihan lulusan. Namun demikian persentase lulusan yang bekerja pada lembaga pemerintahan menunjukkan tren semakin menurun. Kemudian pilihan bekerja pada perusahaan swasta menunjukkan arah sebaliknya, yaitu memiliki tren yang meningkat. Sedangkan tren bekerja pada lembaga sosial masyarakat memiliki tren yang parabolik.
Menurunnya tren bekerja pada lembaga pemerintahan disebabkan oleh menurunnya lowongan PNS yang dibuka oleh pemerintah dalam beberapa tahun terakhir. Kemudian disisi lain, informasi lowongan pekerjaan pada perusahaan swasta banyak beredar di media sosial dan jejaring alumni yang disebarkan oleh lembaga pusat karir pada masing-masing universitas . Sementara itu naik turunnya lulusan yang bekerja pada lembaga sosial masyarakat lebih disebabkan oleh faktor pendapatan dan jenjang karir pada lembaga tersebut.

\section{KESIMPULAN}

Bekerja baik sebagai karyawan pada instansi pemerintahan maupun perusahaan swasta merupakan pilihan utama lulusan perguruan tinggi swasta, sedangkan menjadi wirausaha menjadi alternatif lainnya. Selain itu tren bekerja pada lembaga pemerintahan menunjukkan penurunan yang signifikan, berbanding terbalik dengan tren bekerja pada perusahaan swasta. Penelitian ini juga menunjukkan tren menjadi wirausaha yang cenderung mengalami peningkatan.

\section{SARAN}

Berdasarkan pada hasil penelitian ini, maka perguruan tinggi swasta perlu menjalin kerjasama dengan berbagai perusahaan swasta dalam penyusunan kurikulum dan kegiatan pembelajaran agar dapat memenuhi kebutuhan perusahaan tersebut. Selain itu perguruan tinggi swasta juga perlu meningkatkan life skill lulusannya, sehingga mampu berpikir inovatif, adaptif, dan solusional, serta kemampuan untuk melihat peluang usaha dalam berbagai kondisi dimasa depan.

\section{REFERENSI}

Alam, S. (2016). Tingkat Pendidikan dan Pengangguran di Indonesia (Telaah Serapan Tenaga Kerja Sma/Smk dan Sarjana). Jurnal Ilmiah Bongaya, 250-257. 
Badan Pusat Statistik. (n.d.). Retrieved July $\quad 9$, 2020, from https://www.bps.go.id/statictable/ 2009/04/16/972/pengangguranterbuka-menurut-pendidikan-tertinggiyang-ditamatkan-1986---2019.html

Disas, E. P. (2018). Link and Match sebagai Kebijakan Pendidikan Kejuruan. Jurnal Penelitian Pendidikan, 18(2), 231-242.

Enders, J., \& Teichler, U. (1997). A victim of their own success? Employment and working conditions of academic staff in comparative perspective. Higher Education, 34(3), 347-372. https://doi.org/10.1023/A:1003023923 056

Herbalife Survey: 7 in 10 People in Asia Pacific Aspire to Be Business Owner. (2019, June 20). Direct Selling News. https://www.

directsellingnews.com/herbalifesurvey-7-in-10-people-in-asia-pacificaspire-to-be-business-owner/ Higher education and the world of work: What's the evidence behind educational policies? (2015, June 16). IIEP-UNESCO.

http://www.iiep.unesco.org/en/ highereducation-and-world-work-whatsevidence-behind-educational-policies319

Kogan, M., \& Brennan, J. (1993). Higher Education and the World of Work: An Overview. Higher Education in Europe, 18(2), 2-23. https://doi.org/10.1080/037977293018 0202

Supriati, S., \& Handayani, T. (2018). $\begin{array}{lrr}\text { RELEVANSI } & \text { LULUSAN } \\ \text { PERGURUAN TINGGI DALAM } \\ \text { PENEMPATAN KERJA. JOURNAL } \\ \text { OF APPLIED } & \text { BUSINESS } \\ \text { ADMINISTRATION, 2(2), } & 218-227 .\end{array}$ https://doi.org/10.30871/jaba.v2i2.112

1

Teichler, U. (1999). Research on the relationships between higher education and the world of work: Past achievements, problems and new challenges. Higher Education, 38(2), 169-190.

https://doi.org/10.1023/A:1003761214 250 